\title{
A Scenario for the Past: Colonial Virginia in History and Ethnography
}

\section{Citation}

Faust, Drew Gilpin, and Rhys Isaac. 1984. "A Scenario for the Past: Colonial Virginia in History and Ethnography." American Quarterly 36 (1): 135.

\section{Published Version}

doi:10.2307/2712842

\section{Permanent link}

http://nrs.harvard.edu/urn-3:HUL.InstRepos:12008818

\section{Terms of Use}

This article was downloaded from Harvard University's DASH repository, and is made available under the terms and conditions applicable to Other Posted Material, as set forth at http:// nrs.harvard.edu/urn-3:HUL.InstRepos:dash.current.terms-of-use\#LAA

\section{Share Your Story}

The Harvard community has made this article openly available.

Please share how this access benefits you. Submit a story.

\section{Accessibility}




\title{
A SCENARIO FOR THE PAST: COLONIAL VIRGINIA IN HISTORY AND ETHNOGRAPHY
}

\author{
DREW GILPIN FAUST \\ University of Pennsylvania
}

The Transformation of Virginia, 1740-1790. By Rhys Isaac. Chapel Hill: University of North Carolina Press, 1982.451 pages. $\$ 29.50, \$ 9.95$ (paper).

IN THE TRANSFORMATION OF VIRGINIA, 1740-1790, RHYS ISAAC PRESENTS an interpretation of southern colonial culture equal in insight and synthetic power to that provided for New England by Perry Miller two generations ago. A decade of studies by a dozen scholars of the Chesapeake have furnished Isaac with much of his background and detail, but his book is unique in its form and method, as well as its substance. The originality of its approach, in fact, constitutes an important clue as to why colonial Virginia had to wait so long for its interpreter. Only with Isaac's innovative methods could the structures of perception of early Virginians be made as accessible as those of sermon-writing and diary-keeping New Englanders. Only when horses and houses could be read like words did eighteenthcentury Virginians begin to speak to us so clearly. Isaac's book is thus an important study of Virginia culture on the eve of the Revolution and, at the same time, an explicit effort "to seek concepts and methods for gaining an understanding of past people and so to contribute a mite to humanistic historical social science"'(7). The persuasiveness of his conclusions makes the strongest possible case for the usefulness of his methods.

In his previous work, Isaac's most important substantive contribution has been his exploration and explication of the profound cultural conflict between religious evangelicals and the gentry in mid-eighteenth-century 
Virginia. Following close on the heels of the consolidation of gentry dominance, the Great Awakening presented fundamental challenges to the assertive, hierarchical values on which planter power was based. Isaac opens his book with a portrait of the foundations of gentry hegemony designed to set the stage for what is to come. It is a synchronic view, one explicitly influenced by anthropological notions of cultural ethnography. The participants' understanding of their world is of central significance to Isaac, and he hopes to help us to see the cosmos through their eyes. Images, tableaux vivants, shapes, spaces, and occasions make the text itself nearly as visual an experience for the reader as do the numerous illustrations chosen to accompany it. Yet we must not simply see these vignettes, we must learn to read them, for in that reading lies access to the meaning of the Virginia experience.

In his introduction, Isaac admits a conscious effort at "experimenting with strategies of presentation" (5), as well as methods of analysis, and this purpose is clear in the form and structure of the book. Isaac uses no overall narrative line in the traditional historical sense of a more-or-less chronological, syllogistic argument linked by clear transitions. Instead, The Transformation of Virginia is a bit like a slide show in which the inherent interrelatedness and integration of eighteenth-century Virginia culture provides the logical connections. Behavior at court, in church, in the taverns, at the races, on the militia field, at the polls represent in microcosm or in forceful display the wider patterns of hierarchical, graded social assumptions that lie at the heart of the culture.

The physical appearance of great houses and even rural landscapes similarly mirrors cultural values. Communal gatherings on court days transmit to the people at large the sources and symbols of judicial power in the same way that periodic militia musters underline the ultimate coercive authority invested in Virginia's white màles. The customs of "treating" and oral voting on election days reinforce the paternalistic bonds between the gentry and their neighbors, while in the realm of sport, horse racing and cockfighting confirm social ranking within a wider context of collective interaction. Church seating plans display the community in hierarchical order, emphasizing the divine underpinnings of terrestrial arrangements. The elaborate dwellings of planters, often sited so as to be visible to all passers-by, contrast sharply and meaningfully with the humble cottages of both lesser whites and slaves. Rituals of hospitality accent the wealth that underlies gentry status and transform private houses into significant public places. Through exploration of symbol and metaphor evident in spaces, buildings, ceremonies, and occasions, Isaac recaptures these Virginians' world view as forcefully as if he had had the explicit articulations of communal belief so readily available to Perry Miller in New England 
Puritan writings. For Isaac, behavior and objects become the equivalent of texts.

Isaac's book represents the culmination of more than a decade of interchange between American historians and cultural anthropologists, most especially Clifford Geertz. Yet while numbers of historians have invoked Geertz, Isaac has made most successful use of him, incorporating Geertz's insights into a perspective that nevertheless remains very much Isaac's own. His approach is distinctively that of the historian, confronted not by living subjects, but by the limited evidence left by a past civilizationcommitted not just to ethnography, but to history, to the vexing problem of change over time.

Part Two of The Transformation of Virginia faces this challenge of change, moving away from the synchronic portrait of Part One to diachronic description. Elite Virginia culture is forced to confront not only the threat of growing Baptist strength. A series of events-Parsons' Cause, the episcopacy controversy, conflict over the succession at Bruton Parish, and, ultimately, disestablishment-mark the religious manifestations of the growing upheaval in Virginia society, an upheaval that is expressed most dramatically in the outbreak of the Revolution. Yet Isaac's account of change and movement in Virginia is no traditional narrative of the coming of independence. Instead we have here again the vignettes, the glimpses of particular moments intended to bear disproportional significance in their contributions to Virginians' changed images of themselves. In this context, events and occasions do not simply embody, but alter existing patterns of Virginia life.

By 1790 Virginians embrace new metaphors of social order: individualism and contractualism replace communalism; houses begin to reflect their occupants' retreat into privatism; slavery no longer fits so neatly within prevailing social assumptions. Authority and with it Virginia as a whole have been transformed. Yet the historian of the early nineteenth-century South cannot help wondering how complete this transformation actually was. The crisis of authority that Isaac identifies becomes a central dilemma for antebellum southern culture - and for antebellum southern historianswith the paradoxes of slavery and freedom, democracy and aristocracy at the heart of the civilization of the Old South. Perhaps Virginia gentry power is neither as consolidated in 1740 nor as eroded in 1790 as Isaac's choice of the term "transformation" might lead us to think. His book might instead be seen as an introduction to the persistent problem of the nature of planter hegemony in the pre-Civil War South.

Isaac closes with an appendix on method in which he attempts to articulate the assumptions and procedures that the body of his work has exemplified. The essay demonstrates the eclecticism of his approach; Isaac 
employs linguistic, dramaturgical, structuralist, and symbolic perspectives in an effort to illustrate what Clifford Geertz intended by his much quoted phrase, "thick description." Isaac approaches each of the methods from which he borrows with a refreshingly critical eye, emphasizing the ways in which each is and is not appropriate for the historian. Symbolic analysis, he reminds us, tends to neglect the issue of social power; structural approaches are in themselves too static; dramaturgical models may mislead us into dismissing meaningful behavior as histrionics. Yet used carefully and selfconsciously, Isaac concludes, each of these perspectives has a great deal to offer the historian in search of "systematic method" (357).

Isaac's Appendix makes an important statement to his fellow historians, squeezed as they have been in the past decade between the conflicting demands of science and art. Isaac hopes to impart to qualitative analysis some of the legitimacy of science by transcending intuition and subjectivity. Yet, at the same time, he insists that any method must ultimately be concealed within the actual presentation of the discovered realities of past time; he himself discusses these issues in an appendix, not in the body of his text. "The objective of the ethnographic historian's enterpriseunderstanding and depicting life itself-is . . . very close to the aims of the artist." The "traditional skills of the storyteller" (357), or, and here Isaac more closely describes himself, the "newer forms developed by scenario writers" (357) will translate past lives into terms for our own understanding.

Isaac's book is an admirable undertaking, and his appendix is certainly the best statement of the significance and relevance of the theoretical and methodological experimentations of recent years to historians concerned with nonquantitative matters. Yet one wonders if Isaac has truly found the path to system and objectivity. Certainly his prescriptions can make us all more self-conscious about what we do and can give us access to implications of our data that we may not have seen. Yet Isaac himself admits the paradox in his method. "Ethnographers cannot understand and translate action-statements unless they have some comprehension of the culture; but such grasp can only be effectively acquired by close attention to particular action statements' (325). So does it all come back to intuition after all? One is left with the inescapable conviction that the brilliance of The Transformation of Virginia arises not from Isaac's application of a prescribed and objective method, but from his own more subjective sensitivity and insight. 